\title{
Does Foreign Presence Influence the Level of Firm Technical Efficiency? Evidence from Africa
}

\author{
Anthony Orji, Jonathan E. Ogbuabor*, Gabriel Chiangi Aza*, and \\ Onyinye I. Anthony-Orji \\ *University of Nigeria, Nigeria
}

Submitted: September 27, 2020 • Accepted: December 20, 2020

\begin{abstract}
This study investigates the impact of foreign direct investment on the level of firm technical efficiency in West Africa. Firms from Nigeria, Ghana, Sierra Leone and the Gambia were sampled due to the fact that they used to belong to the British Empire. The data, sourced from the World Bank enterprise survey, covers the period from 2006 to 2018, with the sampled countries having data for different years. A time varying stochastic frontier production function for panel was developed for this enquiry. The findings of the study show that foreign direct investment has a significant and positive impact on both technical efficiency and productivity of firms in West Africa. Controlling for other effects, international trade and firm size both have positive and significant effects on firm level technical efficiency. Therefore, policies should be aimed at encouraging more inflows and maintenance of the stock of foreign direct investment to avert divestments. This includes, but is not limited to, ensuring sociopolitical stability and introducing policies that would remove bureaucratic bottlenecks from the path of direct investment inflow and simplify the process of doing business in these countries.
\end{abstract}

JEL classification: D22, D24, F21, F23.

Keywords: Foreign Direct Investment, Technical Efficiency, Stochastic Frontier Analysis.

*Corresponding Author. E-mail: onyinye.anthony-orji@unn.edu.ng 


\section{Introduction}

The world has become a global village, not only because of communication technology but also in terms of economy. International economic relations have assumed a state where cross border investments are promoted as countries inter-depend on themselves Bassiratu, 2018; Orji et al., 2019). Although economic inter-dependence and cooperation among nations is not a new practice, as it was an important practice of medieval economies, it took a new turn at the beginning of the sixteenth century (Conteh, 2014). Around this period, due to imperialism, European countries built empires around the world aimed at acquiring resources in return for a little expense (Pakenham, 1991). This made foreign investment the thrust of colonial government policy. This was the reality of the seventeenth and the eighteenth century. Global economic relations, as they are nowadays, were birthed with the establishment of modern Westphalia states (Conteh, 2014), and purred by the industrial revolution of the eighteenth century as greater cross border economic ties were realized. One of the ways through which nations cooperate in modern days economically is through foreign direct investment (FDI).

In general terms, foreign direct investment (FDI) is considered a vehicle ferrying tangible and intangible assets such as, for instance, patents, new technology, brand names, better product designs, management skills from developed and technologically advanced economies to developing economies Arnold and Javorcik, 2009, Wang and Wong, 2016, Anthony-Orji et al., 2018). These assets which are superior, and generally not available to firms in the host country, can spill to local firms; even to those not related or affiliated to the FDI Multinational Corporations (MNCs). This affects efficiency in the receiving country. Thus, while drawing development policy plans, countries consider FDI as an integral part of the whole process as they aim to attract it. To achieve this, they offer a wide range of fiscal and financial incentives to foreign firms such as tax breaks, subsidies, among others (Orji et al., 2015; Wang and Wong, 2016).

Not surprisingly then, African leaders, like other developing countries' rulers, have become gracious to foreign investors by offering fiscal and investment incentives to attract and retain FDI - just as there has been considerable debate for many years on the spillover effect of FDI on domestic firms' performance. Studies on FDI spillovers have attracted attention from both academia and policy makers since the publishment of the pioneering work of Caves (1974).

Although inflows to Africa have been negligible compared to the world total flows, African leaders have continued to seek ways to bring more direct inflows to the subregion hoping its spillovers would spur efficiency (Orji et al., 2014). In 2016, FDI inflows to West Africa rose by $12 \%$ to $\$ 12.6$ billion, driven by recovering investment into Nigeria. As oil output in Nigeria declined to historic lows in 2016, FDI remained relatively depressed and fell by $11 \%$ to $\$ 11.3$ billion in 2017 in West Africa (UNCTAD, 2018).

Even with turning events in political and economic reforms, recurring vigor in all quarters to attract FDI, the effect of such an important asset on technical efficiency of 
firms has not been fully examined quantitatively in the African context. Just a few studies have been conducted to relate to foreign investment and technical efficiency in Africa. This research exploits institutional, economic and social regional similarities between former British colonies in West Africa to assess this relationship.

This paper is further divided into four sections. Section 2 includes theoretical presentation of efficiency and relates to foreign direct investment and technical efficiency. Section 3 discusses the methodology. Section 4 presents the results of the study and offers the discussion. Section 5 is devoted to conclusions and policy implications.

\section{Review of Literature}

\subsection{Conceptual, Theoretical and Empirical Clarifications}

\subsubsection{Foreign Direct Investment in Africa}

According to Kunle et al. (2014), foreign direct investment (FDI) is an investment into production or business in a local country by an individual or a foreign company, either by whole purchase of such a company in the target country or by operation expansion of an existing business in such a local country. Foreign direct investment differs from flaccid portfolio investments in foreign country securities such as stocks and bonds. Macaulay Egbo (2012) and World Bank (2017) thought of foreign direct investment (FDI) as an investment that is made to acquire a long-term management interest (usually 10\%) in a venture operating in a foreign country; the investors purpose being co-management of the enterprise and subsequent earning on either long-term capital or short-term capital as shown in the nations balance of payments account statement.

FDI, not limited to capital, encompasses all resources including technology, marketing and managerial proficiency, which substantially impact a host nation's capabilities in terms of productivity. This is due to the fact that the success of government policies towards stimulating the productive base of the economy is impacted by their ability to attract adequate amount of FDI comprising of technological, managerial and capital resources and optimally allocating same to boost the existing production capacity (Ehimare, 2011). Therefore, foreign investment is seen as a way of bridging the gap between the domestically available supplies of investment reserves, government revenue, foreign exchange and human resources and the desired level of these resources essential to achieve growth and development goals of a nation (Aswathappa, 2015). It can play an important role in an economy's development efforts as it supplements local savings, helps to generate employment and enhance growth. Moreover, it further enhances global integration, supports transfer of modern technologies, and plays a key role in local manpower skill advancement (Dupasquier and Osakwe, 2003; Anyanwu, 2006). While Africa is not a major recipient of FDI lagging other regions of the world, it is a critical source of long-term capital for investment in infrastructure and other developmental initiatives and a catalyst 
for economic diversification.

The image of Africa as a location for foreign direct investment (FDI) has not been a favorable one. Too often has Africa been associated only with pictures of civil unrest, starvation, deadly diseases and economic disorder, which has resulted in a situation in which many investors have been given a negative or unfair picture of Africa as a whole. While this picture is not based on fiction, and in some countries these unfortunate conditions prevail, it is not a true picture of the majority of African countries.

In 1990s, African countries significantly liberalized the environment for foreign investment. Nearly all countries revised their national laws governing FDI and the vast majority lifted controls on capital (UNCTAD, 2017). Despite these substantial changes, Africa has not received the levels of FDI that had been expected by reformers (Moss et al., 2004).

\subsubsection{Foreign Investment in West Africa: Background}

Given this context, we shall now turn to three cases studies in West Africa: Nigeria, Ghana, Sierra Leone and The Gambia. In 1995, through the Nigerian Investment and Promotion Commission (NIPC), Nigeria opened nearly all sectors to foreign investment dismantling years of restrictions (UNCTAD, 2018). Over time, through legislations, the country has continued to seek ways to attract more inflows. As reported by UNCTAD (2017), over the period from 2007 to 2011, the country attracted an average of $\$ 8$ billion of FDI inflows annually. This was backed by several policies which included the National Tax Policy and the Presidential Technical Committee on Land Reform. From 2012 to 2014, however, the country experienced a decline in inflows to $\$ 7.1$ billion in 2012 and still further down to $\$ 5.6$ billion in 2013. According to UNCTAD (2019), this was due to nonimplementation of National Tax Policy and the Presidential Technical Committee on Land Reform, insecurity and uncertainty in the presidential election of 2011. Crashing oil prices further aggravated the decline in inflows to $\$ 4.6$ billion in 2014 and continued through the 2015 also further influenced by the uncertainty relating to the 2015 general elections. After the elections, the free fall continued through 2016. This crisis, however, triggered urgent policy interventions. As a result, Economy Recovery Growth Plan (ERGP) 2017-2020 was formulated. It targets, among other things, rebuilding investor confidence (UNCTAD, 2019). After consecutive increases in 2017 and 2018, inward FDI to Nigeria nearly halved - to $\$ 3.3$ billion in 2019 , due to a slowdown in investment in the oil and gas industry (UNCTAD, 2020).

The civil war which ended in 2002 inflicted significant damage on Sierra Leone. Since then, the country has committed itself to reestablishing the conditions necessary for growth. Therefore, the attraction of FDI has become a central element in their national development strategy (UNCTAD, 2019). In 2014, the country enacted the Investment Promotion Act 2004 assigning business facilitation duties to the Sierra Leone Export Development and Investment Corporation (UNCTAD, 2018). It was later replaced by the Sierra Leone Investment and Export Promotion Agency (SLIEPA). Since then, FDI in- 
flows increased significantly between 2007 and 2011 in comparison to the previous period. Unfortunately, this was then influenced by the outbreak of Ebola, leading to a drop in its lowest level since 2010 at 129 million. Yet, subsequently, tt managed to grow. Factors inimical to FDI flows into the country are shortage in skilled manpower, high level of corruption, slow legal system and social disorder due to social economic disparities amongst others.

The Gambia in its bid to attract FDI offers simple and transparent investment procedures and tax incentives. (UNCTAD, 2019) reports, however, that FDI has been on a downward trend since 2007. According to the document, the downward run of FDI inflows into the country result from the outbreak of Ebola, policy instability and uncertainty and vulnerability of Gambia's market to external shocks. However, with the activities of the Gambian Investment and Export Promotion agency (GIEPA) carrying out its function of promoting investment and export, there seems to be light at the end of the tunnel as UNCTAD (2019) reports that FDI inflows increased to $\$ 18$ million in 2017 and $\$ 29$ million in 2018.

Ghana on its part has overtime made efforts to attract FDI which has recently paid off with the country becoming a major recipient of FDI in West Africa (UNCTAD, 2019), topping the highest recipient country for two years running. This increased inflow of FDI is partly due to the recent discovery and commencement of exploration of oil in the country (OECD, 2018). The country has continued to make efforts through the GIPC to simplify the complex and lengthy procedures while offering tax incentives too. The increase in inflows to Ghana according to UNCTAD (2019) can be explained by the democratic nature of the country, its large and inexpensive labour force, numerous natural resources and stable institutions. The country is however not free from challenges affecting the free inflow of FDI. According to UNCTAD (2018), they include weakly productive and unskilled labour, cumbersome administrative processes, corruption and power.

Although, on the whole, inflows to Africa have been negligible compared to the world total flows, African leaders have continued to seek ways to bring more direct inflows to the subregion hoping its spillovers would spur efficiency and productivity.

\subsubsection{Efficiency, Foreign Direct Investment and Technical Efficiency}

According to Suyanto and Salim (2011), seminal literature on FDI treated productivity spillovers as synonymous with technological spillovers. The impact of FDI on productivity of domestic firms then appeared solely as a shift in the production curve using a standard production function which assumes full efficiency production. Positive spillovers were represented simply by an upward shift of the production curve while a shift downward represented negative spillovers. In recent literature however, the full efficiency assumption is relaxed as technological efficiency has been successfully differentiated from technical efficiency. Thus, the benefits of FDI appear both as advancement in technology (represented by a shift in production curve) and improvement in technical efficiency (shown by 
movement to the most efficient level given a set of inputs).

Therefore, the concept of productivity in research should not be treated synonymously with that of efficiency (Svedin and Stage, 2016). While productivity reflects a firm's output ratio to its productive inputs, efficiency appraises the achieved output as it relates to the maximum possible output from a given amount of productive inputs or the ratio of minimum potential input required in producing a given output.

Battese (1992) views technical efficiency of a given firm as the factor by which the level of production for the firm is less than its frontier output. He further avers that the technical efficiency of an individual firm is defined in terms of the ratio of observed output to the corresponding frontier output, given the levels of inputs used by that firm. According to Palmer and Torgerson (1999), technical efficiency refers to the physical relation between resources (capital and labour) and a desired outcome. A technically efficient position is achieved when the maximum possible improvement in outcome is obtained from a set of resource inputs. An outcome is technically inefficient if the same (or greater) outcome could be produced with less of one type of input. In his own submission, Pettinger (2017) says that technical efficiency is the effectiveness with which a given set of inputs is used to produce an output. A firm is said to be technically efficient if it produces the maximum output from the minimum quantity of inputs, such as labour, capital, and technology. It requires no unemployment of resources. Given a certain quantity of inputs (natural resources), technical efficiency is achieved when the maximum output possible is produced. Technical efficiency in this study would then mean the effectiveness with which a given set of inputs is used to produce an output.

Although measurement of efficiency is a relatively new issue, the first author to shed light on its measurement being Farrell in 1957, modeling of FDIs effect on technical efficiency has come to be a field drawing much concerned attention ( $\mathrm{Vu}, 2016)$. Dimelis and Louri (2002) identified positive FDI spillovers on Greece's domestic firms. Ghali and Rezgui (2011) drew a similar conclusion presenting their analysis of the Tunisian manufacturing sector.

Moran et al. (2005) showed that resources in a host country were more efficiently used by foreign companies and that spillovers, due to foreign ownership of local business, greatly contributed to efficiency of such businesses. This, however, is not a given. Several duplicate functions arise when a firm is owned by foreigners including: reporting to local authorities, relation building and preservation with local staff and suppliers as well as marketing. These indeed form costs that are deal breakers of multinational companies' decisions on producing abroad or otherwise, and these added costs could potentially negatively affect the efficiency of local firms that become foreign-owned (Markusen, 2002; Bürker et al., 2013).

According to Mahembe and Odhiambo (2016), FDI can effectively enhance competition both at firm and market levels which could spur increased efficiency. This effect does not go without an input from the investment climate of the recipient country. According 
to Kinda (2012), recipient country investment climate has a verifiable effect not only of the efficiency impact of FDI firms but also on non FDI or local firms acting as suppliers to them. By implication, whether FDI firms or fully foreign owned firms would grow in efficiency or not, is dependent on the recipient country and on the sector. According to Badunenko et al. (2006), technical efficiency is dependent on the firm's headquarters' location, its size as well as research and development intensity. This is partially corroborated by Lundvall and Battese (2000) who considered the firm size and reported a similar effect. According to them, a firm's size affects its technical efficiency. Moreover, the labour quality and the capital intensity were identified by Mahadevan (2000) as determinants of technical efficiency. $\mathrm{Vu}(2016)$ identified location, human capital and export activities as key determinants of technical efficiency.

FDI and foreign ownership's impact on efficiency have been studied and the literature suggests that it is growing though still scanty compared with the enquiry of its impact on productivity. As stated by Svedin and Stage (2016), whether FDI leads to efficiency growth as opposed to mere growth in productivity has gone beyond an academic issue.

\section{Model Specification}

The literature classifies spillover analysis methodology into parametric and non-parametric methods. There are two most popular estimation methods: the non-parametric Data Envelopment Analysis (DEA), involving a linear programing model, originally proposed by Charnes et al. (1978) and the parametric Stochastic Frontier Analysis introduced by Aigner et al. (1977) and Meeusen and van Den Broeck (1977).

The DEA is deterministic because efficiency is measured as the distance to a nonparametric frontier which is determined by the most efficient producers in a data set without involving statistical noise. It is, therefore, sensitive to outliers and causes unpredictability of measurement errors biasing the efficiency measures (Sari et al., 2016). The parametric Stochastic Frontier Analysis, on the other end, introduced by Aigner et al. (1977) and Meeusen and van Den Broeck (1977) independently, though containing the same structure, is a regression-based approach assuming a production function and specific distributions for statistical noise. It contains two error components: the first measuring the statistical noise and the second capturing the technical inefficiency of firms of firm's production.

In later studies, Kumbhakar et al. (1991), Huang and Liu (1994) and Battese and Coelli (1995) extended the model allowing for the simultaneous estimation of the impact of environmental and other external factors. A time varying stochastic frontier production function for panel is developed for this enquiry. It seeks to quantify the effects of FDI spillovers on the technical efficiency of a firm.

Following Sari et al. (2016), the stochastic frontier model for panel can be specified as 
follows:

$$
\begin{aligned}
y_{i t} & =\beta_{0}+x_{i t} \beta+z_{i t} \tau+v_{i t}-u_{i t} \\
u_{i t} & =\delta_{0}+z_{i t} \delta+w_{i t}
\end{aligned}
$$

where the use of small letters signifies that all representation are in natural logs, $y_{i t}$ is the output of the $i$ th firm at the $t$ th time period, $x_{i t}$ is a vector of productive inputs, $z_{i t}$ is a vector of exogenous variables affecting efficiency, while $\beta_{0}$ and $\delta_{0}$ are intercepts; $\beta, \tau$ and $\delta$ are vectors of unknown parameters to be estimated. $v_{i t}$ is a random error assumed to be $i i d N\left(0, \sigma_{v}^{2}\right)$ across all firms, while $u_{i t}$ is the inefficiency effect. Both $v_{i t}$ and $u_{i t}$ are assumed to be distributed independently for different firms and years.

Theoretical arguments, as presented in Sari et al. (2016), indicate that gains of FDI do not only come from technological benefits, but also from efficiency improvements. A way to incorporate these variables into the stochastic frontier approach is by including FDI variable in both the production function and inefficiency function.

In the panel framework, the inefficiency effect $u_{i t}$, is assumed either to be time varying or time invariant. Restricting the inefficiency effect as time varying, in line with Battese and Coelli (1995), gives flexibility and allows for the possibility that a firm's inefficiency can vary over time. Under the time varying inefficiency effect, $u_{i t}=u_{t}$.

While equations (1) and (2) are log linear in parameters, the stochastic production frontier is widely specified in translog form. The stochastic translog production function is a flexible functional form used in testing the spillover hypothesis. It is subject to fewer constraints as it is characterized by non-fixed substitution elasticity (Christensen et al. 1973; Heathfield and Wibe, 1987). Risk of errors is greatly reduced by adopting this flexile functional form (Kopp and Smith, 1980).

The transformation of (1) and (2) for one output and $n$ inputs case thus yields:

$$
\begin{gathered}
y_{i t}=\beta_{0}+\sum_{n=1}^{N} \beta_{n} x n_{i t}+\frac{1}{2} \sum_{n=1}^{N} \sum_{m=1}^{N} \beta_{n m} x n_{i t} x m_{i t}+\beta_{t} t+\frac{1}{2} \beta_{t} t^{2}+ \\
+\sum_{n=1}^{N} \beta_{n t} x n_{i t} t_{i t}+\sum_{k=1}^{K} \beta_{k} Z k_{i t}+v_{i t}-u_{i t} \\
u_{i t}=\delta_{0}+\sum_{k=1}^{K} \delta_{k} Z K_{i t}+\omega_{i t}
\end{gathered}
$$

Where $y$ is the total output and $x n$ is a vector of productive inputs, in this case: capital, labour, material and energy. All variables are in natural logarithm expressed in deviation from their geometric means. $Z k$ is a vector of variables exogenous to the firm that affect firm productivity through efficiency, while $\delta$ is a vector of coefficients to be estimated, and $\omega_{i t}$, an error term in the inefficiency equation. All undefined variables 
remain as earlier undefined.

\subsection{Data Sources and Variables Construction}

Firm level data for the sampled countries: Ghana, Nigeria, Sierra Leone and the Gambia was sourced from the World Bank Enterprise Survey. The original dataset contained a total of 7898 firms. A good number of these firms were however dropped from the final dataset used for the analysis. Since efficiency change may only be obtained from a firm with at least a two-year period panel, all firms with data for a single year were dropped, bringing the total numbers of firms to 1989 with 3978 observations. Furthermore, all firms with over $50 \%$ loss of information were dropped from the dataset, bringing the firm count down to 889 with 1778 observations. Interpolation was finally carried out to fill the few cases of data loss that was still noticed. A two-time period panel of 889 firms made up the dataset utilized to achieve the objectives of this study.

Table 1: Sample Distribution of Data Set Used in The Study

\begin{tabular}{|c|c|c|c|c|c|c|c|c|c|c|c|c|c|}
\hline \multirow[b]{2}{*}{ COUNTRY } & \multirow{2}{*}{ 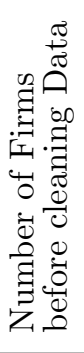 } & \multirow{2}{*}{ 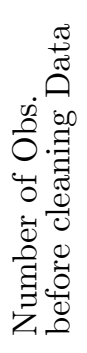 } & \multirow[b]{2}{*}{ 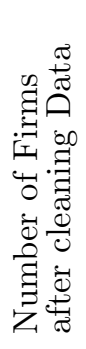 } & \multirow{2}{*}{ 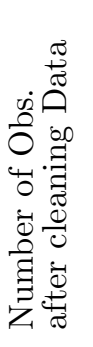 } & \multicolumn{2}{|c|}{ Ownership } & \multicolumn{3}{|c|}{$\begin{array}{c}\text { Activities/ } \\
\text { Industry }\end{array}$} & \multicolumn{4}{|c|}{ Firm Size } \\
\hline & & & & & 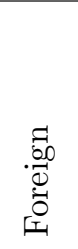 & 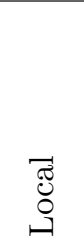 & 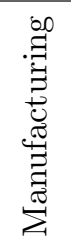 & 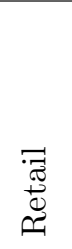 & 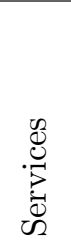 & 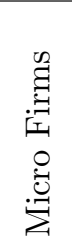 & 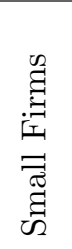 & 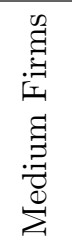 & 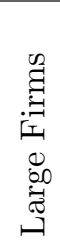 \\
\hline Ghana & & & & & & & & & & & & & \\
\hline $2007 \& 2013$ & 31 & 62 & 31 & 62 & 10 & 52 & 44 & 10 & 8 & 2 & 33 & 16 & 11 \\
\hline Sierra Leone & & & & & & & & & & & & & \\
\hline $2009 \& 2017$ & 151 & 302 & 75 & 150 & 28 & 122 & 78 & 0 & 72 & - & 90 & 40 & 20 \\
\hline Gambia & & & & & & & & & & & & & \\
\hline $2008 \& 2018$ & 127 & 127 & - & - & - & - & - & - & - & - & - & - & - \\
\hline Nigeria & & & & & & & & & & & & & \\
\hline $2007 / 2009 \& 2014$ & 7437 & 8220 & 783 & 1566 & 108 & 1458 & 316 & 848 & 402 & 209 & 846 & 404 & 107 \\
\hline TOTAL & 7746 & 8711 & 889 & 1778 & 146 & 1632 & 438 & 858 & 482 & 211 & 969 & 460 & 138 \\
\hline
\end{tabular}

Input and output variables make up the main variables of a production function, the production frontier model is not an exception. Capital stock, labour, materials and energy make up the input variables while the output variable is proxied by total gross output following Suyanto et al. (2012). Lands, buildings, machinery and other capital goods make up the capital stock measured by replacement value of fixed assets, labour is measured by the number of employees, material is the total cost of materials used in production process sourced both locally and imported, while energy measures the total expenditure on gasoline, lubricants and electricity in the production process.

Other variables (control variables), used in the study, include $F D I$, a dummy variable 
for foreign presence. It is equal to 1 , for firms with equity share of foreign ownership at the observed time greater than $5 \%$, and 0 , otherwise. We take the $5 \%$ threshold following Haddad and Harrison (1993). Another dummy variable Trade, takes the form 1 when a firm engages in international trade (import or export) or 0, otherwise. This is used following Sun and Heshmati (2010) who show in their separate studies that firms enjoy positive and dynamic efficiency changes from international trade such as competition effects, scale effects and technology effects which positively affect efficiency.

Firm size (Firm_size) according to Dang et al. (2018) is an important variable determining productivity because it captures the economies of scale. Large firms ordinarily produce in high volumes ensuring low unit cost. Therefore, there is an expected positive relationship between firm size and productivity. Following Ramaswamy (1994) and Konara et al. (2015), firm size is a categorical variable representing how large a firm is. A firm is represented by 1 if it has fewer than 5 employees, 2 represents between 6 and 19 employees, 3 is used when a firm employs between 20 and 99 employees, and 4 is used to represent a firm employing over 99 employees. Although firm size is measured by other standards in other studies, which may be more acceptable, employment numbers are used in this study because of data availability.

\subsection{Estimation Technique}

The stochastic frontier model will be estimated using the method of maximum likelihood under the distributional assumption that the inefficiency effect is time varying $\left(u_{i t}=u_{t}\right)$ and that the inefficiency effect $u_{i}$ is identically and independently distributed variable in line with Battese and Coelli (1995) truncated normal distribution $u_{i} \sim \operatorname{NIID}\left(\mu, \sigma_{u}^{2}\right)$.

The maximum likelihood involves the maximization of the log likelihood function thus producing maximum likelihood estimates with desirable properties of asymptotic consistency and efficiency.

\subsection{Diagnostic Test}

\subsubsection{Test of Null Efficiency Effects: Likelihood Ratio Test}

The test to be conducted here is to check whether or not there is an absence of inefficiency effects which would render the use of stochastic frontier model unnecessary. The likelihood ratio test statistic was recommended by Kumbhakar et al. (2015).

Here, $H_{0}$ states that there is a case of null technical inefficiency and the alternative, otherwise:

$$
-2\left[L\left(H_{0}\right)-L\left(H_{1}\right)\right]
$$

where $L\left(H_{0}\right)$ and $L\left(H_{1}\right)$ represent the log-likelihood values computed from restricted ordinary least squares model and the unrestricted stochastic frontier model respectively with $5 \%$ degree of freedom restriction. The value of the above computation will be compared 
to the critical values of inequality restrictions at $1 \%$ restriction relating to the variance of the technical inefficiency component. If the calculated value is greater than the critical value, we reject the null hypothesis, otherwise, we accept it. Critical values for the mixed distribution are obtained from Kodde and Palm (1986) table of inequality restrictions.

\section{Result Presentation and Discussion}

Based on the methodology described in the previous section we first test for null efficiency effects which determines the use of a restricted model or an unrestricted model. In the event of null efficiency effect, the ordinary least squares (OLS) estimator will generate consistent estimates and will be preferred to the maximum likelihood estimator (MLE), the method of estimating the stochastic frontier methodology, the proposed model. The calculated value from this procedure, 502.276, is higher than the critical value of 5.412 (from Kodde and Palm (1986); see appendix A at 1 degree of freedom relating to the variance of the technical inefficiency component and at $1 \%$ level of significance. Inferring from this, we reject the null hypothesis of null technical inefficiencies and state that the MLE is the preferred estimator and thus the stochastic frontier model is appropriate.

A translog stochastic production function is thus estimated and the results are presented in table 2, where $\operatorname{lnk}$ represents the log of capital, $\operatorname{lnl}$ the log of labour, $\operatorname{lnm}$ the $\log$ of materials and $\operatorname{lnksq}$, the square of the $\log$ of capital. $\operatorname{lnk} l n l$ is an interaction of the log of capital and the log of labour while for is foreign direct investment, trade, a variable defining if a firm engages in foreign trade or not. The result in table 2 is divided into two parts: the estimated coefficient of inputs on the production frontier and the estimated coefficients of foreign direct investment and the control variables on the inefficiency function $(M u)$. The study will however consider only FDI spillover and control variable effects in the inefficiency function. Though the coefficients of the production function can be used to evaluate the output elasticities with respect to each input as well as elasticities of substitution between capital and labour, they are irrelevant to the aim of this study. Therefore, they are not considered.

Considering the estimates of the inefficiency function, the coefficient of foreign direct investment (for) is negative and significant at $5 \%$ level of significance showing that foreign direct investment has positive impact on firm's efficiency or that firms with foreign investment are more efficient than domestic firms holding other things constant. It is worth noting that the function is an inefficiency function, thus, a negative sign here implies a positive effect on efficiency. Given that only $8 \%$ of sampled firms have foreign investment to their ranks, the general low level of technical efficiency of firms in this region as shown by the analysis (appendix B could be explained. Regardless of firm, industry or country, a mean efficiency level of $30 \%$ was recorded, while the least efficient firm operates at $13 \%$ efficiency. The analysis of individual efficiency scores shows that foreign affiliated firms operate at $58 \%$ efficiency and purely locally owned firms at $28 \%$. 
Table 2: Impact of Foreign Direct Investment on Firm Level Efficiency

\begin{tabular}{|c|c|c|}
\hline & (1) & $(2)$ \\
\hline VARIABLES & Frontier & $M u$ \\
\hline $\ln k$ & $\begin{array}{c}0.808^{* * *} \\
(0.160)\end{array}$ & \\
\hline $\operatorname{lnl}$ & $\begin{array}{c}-1.793^{* * *} \\
(0.347)\end{array}$ & \\
\hline $\operatorname{lnm}$ & $\begin{array}{c}-0.376^{*} \\
(0.194)\end{array}$ & \\
\hline $\ln e$ & $\begin{array}{c}1.384^{* * *} \\
(0.151)\end{array}$ & \\
\hline $\operatorname{lnksq}$ & $\begin{array}{c}-0.0391^{* * *} \\
(0.00785)\end{array}$ & \\
\hline $\operatorname{lnlsq}$ & $\begin{array}{c}-0.0715^{* *} \\
(0.0337)\end{array}$ & \\
\hline lnesq & $\begin{array}{c}0.0354^{* * * *} \\
(0.00488)\end{array}$ & \\
\hline $\operatorname{lnmsq}$ & $\begin{array}{c}0.0716^{* * *} \\
(0.0103)\end{array}$ & \\
\hline $\ln k \ln l$ & $\begin{array}{l}-0.0182 \\
(0.0235)\end{array}$ & \\
\hline lnklne & $\begin{array}{c}-0.0189^{*} \\
(0.0104)\end{array}$ & \\
\hline $\operatorname{lnklnm}$ & $\begin{array}{c}0.0330^{* *} \\
(0.0131)\end{array}$ & \\
\hline lnllne & $\begin{array}{c}0.100^{* * * *} \\
(0.0204)\end{array}$ & \\
\hline $\operatorname{lnllnm}$ & $\begin{array}{c}0.109^{* * *} \\
(0.0303)\end{array}$ & \\
\hline lnelnm & $\begin{array}{c}-0.148^{* * *} \\
(0.0124)\end{array}$ & \\
\hline year & $\begin{array}{l}-0.309 \\
(0.199)\end{array}$ & \\
\hline for & & $\begin{array}{c}-0.580^{* * *} \\
(0.216)\end{array}$ \\
\hline trade & & $\begin{array}{c}-1.181^{* * *} \\
(0.174)\end{array}$ \\
\hline firm_size & & $\begin{array}{c}-0.310^{*} \\
(0.169)\end{array}$ \\
\hline Constant & $\begin{array}{c}4.368^{* * *} \\
(1.294) \\
\end{array}$ & $\begin{array}{c}2.298^{* * *} \\
(0.765) \\
\end{array}$ \\
\hline Observations & 1,778 & 1,778 \\
\hline Number of panelid & 889 & 889 \\
\hline
\end{tabular}

These supports the assumption that an increase in inflows of FDI would positively affect technical efficiency change in the region. In effect, policies aimed at attracting FDI inflows should be rigorously pursued as it promises to enhance efficiency. Seminal works on the subject by Caves (1974) and Dunning (1988) argued that foreign firms generally 
possess more experience and scale advantage and are thus more efficient than their fully domestic counterparts. Later, De Mello Jr (1997) and Smith et al. (1997) and Zhou (2014) also established that foreign ownership impacts efficiency more than other forms of business ownership because it offers advanced technology, capital investment and superior organizational management. Suyanto and Salim (2011) recorded similar results in the Indonesian pharmaceutical sector.

To control for other effects on efficiency, other variables were included in the inefficiency function. The coefficient of the international trade variable (trade) is statistically significant and negatively associated with technical inefficiency. This shows that firms who engage in international trade are more efficient than firms who do not engage in international trade. Firms who engage in international trade strive to manufacture high standard goods to meet the demands of foreign authorities. Therefore, such firms have to be highly efficient. This explains the very significant change in technical efficiency due to this activity. Once again, this should encourage local and regional authorities to aid local firms through subsidies or tax breaks or other incentives to engage in foreign trade as it will enhance firm efficiency. This finding supports the finding earlier recorded in $\mathrm{Vu}(2016)$. Another variable included to explain sources of technical inefficiency, firm size (firm_size) is negative and significant at $1 \%$ level of significance implying that bigger sized firms are more efficient. According to economic theory, bigger firms stand a chance of reaping the benefits of economies of scale production. This finding, therefore, confirms this economic theory. This was also established by Zhou (2014) and $\mathrm{Vu}(2016)$. Sari et al. (2016) who established that firm size positively affects overall productivity, yet they did not find evidence that it necessarily affects efficiency.

\section{Conclusion and Policy Implications}

A two time period panel of a sample of firms across former British colonies in West Africa was used to investigate the relationship between the existence of foreign direct investment and firm level technical efficiency. Therefore, firms from Nigeria, Ghana, Sierra Leone and the Gambia were sampled. The study established that foreign direct investment significantly impacts firm level productivity in the West African sub-region. According to the study, regardless of the firm or industry, firms in the sub-region, operate at an average efficiency level of $30 \%$, while foreign affiliated firms operate at $58 \%$ efficiency and purely locally owned firms at $28 \%$.. Similar conclusions were earlier reached in seminal studies of Caves (1974) and Dunning (1988). In Africa, Zhou (2014) established similar results on sub-Saharan Africa. Elsewhere, Suyanto and Salim (2011), Sari et al. (2016), Svedin and Stage (2016) and Wang and Wong (2016) established similar results amongst a host of others.

A more robust analysis was not possible given missing data on some variables used in efficiency analysis. Information on variables such as value of inter and intra industry 
transactions, magnitude of foreign direct investment enjoyed by each firm, labour wages, investment in research and development and others were lacking. As a result, forward, backward and horizontal effects of foreign direct investment on efficiency were not estimated, thus their effect on fully domestic firms were not established. Its established effect on foreign firms, however, point to potential spill to fully locally owned firms.

The study shows that a negligible $8 \%$ of sampled firms are foreign affiliates and, as seen in the study, foreign affiliates are more technically efficient. Therefore, policy should be directed at encouraging more inflows and maintenance of the stock of foreign direct investment to avert divestments. This includes, but is not limited to, ensuring sociopolitical stability and introducing policies that would simplify the process of doing business in these countries by removing bureaucratic bottlenecks from the path of direct investment inflow. It is worth mentioning that, simply attracting foreign direct investment does not automatically translate to positive impacts on the firms and by extension, the economy. To fully reap the benefits, efforts should be made by all stakeholders, government and private hands to improve the capacity of fully domestic firms to absorb foreign direct investment spillovers. Such efforts could, for instance, include infrastructural and institutional development and direct investments in research and development.

\section{References}

Aigner, D., Lovell, C. K., and Schmidt, P. (1977). Formulation and Estimation of Stochastic Frontier Production Function Models. Journal of Econometrics, 6(1):21-37.

Anthony-Orji, O. I., Orji, A., Ogbuabor, J. E., and Nwosu, E. O. (2018). Disaggregated Foreign Capital Inflows and Economic Growth in a Developing Economy: Empirical Evidence from Nigeria. Journal of Empirical Studies, 5(1):1-11.

Anyanwu, J. C. (2006). Promoting of Investment in Africa. African Development Review, $18(1): 42-71$.

Arnold, J. M. and Javorcik, B. S. (2009). Gifted Kids or Pushy Parents? Foreign Direct Investment and Plant Productivity in Indonesia. Journal of International Economics, $79(1): 42-53$.

Aswathappa, K. (2015). International business. New Delhi: Tata McGraw Hill Pub. Co.

Badunenko, O., Fritsch, M., Stephan, A., et al. (2006). What Determines the Technical Efficiency of a Firm? The Importance of Industry, Location, and Size. Technical Report 33/2006, Friedrich-Schiller-Universität Jena, Wirtschaftswissenschaftliche Fakultät.

Bassiratu, B. M. (2018). The Effect of Foreign Direct Investment on the Economic Growth of Sierra Leone. International Journal of Information Research and Review, 05(08):5628-5631. 
Battese, G. E. (1992). Frontier Production Functions and Technical Efficiency: A Survey of Empirical Applications in Agricultural Economics. Agricultural Economics, 7(34):185-208.

Battese, G. E. and Coelli, T. J. (1995). A Model for Technical Inefficiency Effects in a Stochastic Frontier Production Function for Panel Data. Empirical Economics, 20(2):325-332.

Bürker, M., Franco, C., and Minerva, G. A. (2013). Foreign Ownership, Firm Performance, and The Geography of Civic Capital. Regional Science and Urban Economics, 43(6):964-984.

Caves, R. E. (1974). Multinational Firms, Competition, and Productivity in Host-Country Markets. Economica, 41(162):176-193.

Charnes, A., Cooper, W. W., and Rhodes, E. (1978). Measuring the Efficiency of Decision Making Units. European Journal of Operational Research, 2(6):429-444.

Christensen, L. R., Jorgenson, D. W., and Lau, L. J. (1973). Transcendental Logarithmic Production Frontiers. The Review of Economics and Statistics, pages 28-45.

Conteh, S. M. (2014). Foreign Direct Investment and Economic Development in Sierra Leone: Challenges and Prospects. PhD thesis, University Of Ghana.

Dang, C., Li, Z. F., and Yang, C. (2018). Measuring Firm Size in Empirical Corporate Finance. Journal of Banking \& Finance, 86:159-176.

De Mello Jr, L. R. (1997). Foreign Direct Investment in Developing Countries and Growth: A Selective Survey. The Journal of Development Studies, 34(1):1-34.

Dimelis, S. and Louri, H. (2002). Foreign Ownership and Production Efficiency: A Quantile Regression Analysis. Oxford Economic Papers, 54(3):449-469.

Dunning, J. H. (1988). The Theory of International Production. The International Trade Journal, 3(1):21-66.

Dupasquier, C. and Osakwe, P. N. (2003). Performance, Promotion, and Prospects for Foreign Investment in Africa: National, Regional, and International Responsibilities. In Eminent Persons' Meeting on 'Promotion of Investment in Africa', Tokyo.

Ehimare, O. A. (2011). Foreign Direct Investment and Its Effect on the Nigerian Economy. Business Intelligence Journal, 4(2):253-261.

Ghali, S. and Rezgui, S. (2011). FDI Contribution to Technical Efficiency in the Tunisian Manufacturing Sector: Evidence from Micro-panel Data. International Economic Journal, 25(2):319-339. 
Haddad, M. and Harrison, A. E. (1993). Are There Positive Spillovers from Foreign Direct Investment? Evidence from Panel Data for Morocco. Journal of Development Economics, 42(1):51-74.

Heathfield, D. F. and Wibe, S. (1987). An Introduction to Cost and Production Functions. London: Macmillan.

Huang, C. J. and Liu, J.-T. (1994). Estimation of a Non-Neutral Stochastic Frontier Production Function. Journal of Productivity Analysis, 5(2):171-180.

Kinda, T. (2012). On the Drivers of FDI and Portfolio Investment: A Simultaneous Equations Approach. International Economic Journal, 26(1):1-22.

Kodde, D. A. and Palm, F. C. (1986). Wald Criteria for Jointly Testing Equality and Inequality Restrictions. Econometrica, pages 1243-1248.

Konara, P., Ha, Y. J., McDonald, F., and Wei, Y. (2015). Introduction: The Rise of Multinationals from Emerging Economies-Achieving a New Balance. In The Rise of Multinationals from Emerging Economies, pages 1-6. Palgrave Macmillan, London.

Kopp, R. J. and Smith, V. K. (1980). Frontier Production Function Estimates for Steam Electric Generation: A Comparative Analysis. Southern Economic Journal, pages 10491059.

Kumbhakar, S. C., Ghosh, S., and McGuckin, J. T. (1991). A Generalized Production Frontier Approach for Estimating Determinants of Inefficiency in US Dairy Farms. Journal of Business \& Economic Statistics, 9(3):279-286.

Kumbhakar, S. C., Wang, H.-J., and Horncastle, A. P. (2015). A Practitioner's Guide to Stochastic Frontier Analysis Using Stata. Cambridge University Press.

Kunle, A. M., Olowe, S., and Oluwafolakemi, F. O. (2014). Impact of Foreign Direct Investment on Nigeria Economic Growth. International Journal of Academic Research in Business and Social Sciences, 4(8):234.

Lundvall, K. and Battese, G. E. (2000). Firm Size, Age and Efficiency: Evidence from Kenyan Manufacturing Firms. The Journal of Development Studies, 36(3):146-163.

Macaulay Egbo, D. (2012). Foreign Direct Investment and the Performance of the Nigerian Economy. In 1st International Technology, Education and Environment Conference, pages 629-633.

Mahadevan, R. (2000). Sources of Output Growth in Singapore's Services Sector. Empirical Economics, 25(3):495-506. 
Mahembe, E. E. and Odhiambo, N. M. (2016). Does Foreign Direct Investment Cause Economic Growth? A Dynamic Panel Data Analysis for SADC Countries. International Journal of Emerging Markets, 11(3):316-332.

Markusen, A. (2002). Sticky Places in Slippery Space: A Typology of Industrial Districts. In The New Industrial Geography, pages 210-146. Routledge.

Meeusen, W. and van Den Broeck, J. (1977). Efficiency Estimation from Cobb-Douglas Production Functions with Composed Error. International Economic Review, pages $435-444$.

Moran, T., Graham, E. M., and Blomström, M. (2005). Does Foreign Direct Investment Promote Development? Peterson Institute.

Moss, T., Ramachandran, V., and Shah, M. K. (2004). Is Africa's Scepticism of Foreign Capital Justified? Evidence from East African Firm Survey Data. Center for Global Development, Working Papers.

OECD (2018). FDI in Figures. Retrieved from http://www.oecd.org/investment/FD I-in-Figures-October-2018.pdf.

Orji, A., Anthony-Orji, O. I., Nchege, J. E., and Okafor, J. (2015). Manufacturing Output and Foreign Direct Investment in Nigeria: A New Evidence. International Journal of Academic Research in Economics and Management Sciences, 4(3):16-28.

Orji, A., Ogbuabor, J. E., Nwosu, E., Anthony-orji, O. I., and Okpala, A. J. (2019). FDI, Remittance Inflows, and Economic Development In A Developing Economy: What Do Nigerian Data Show? Journal of Academic Research in Economics, 11(1):27-45.

Orji, A., Uche, A. S., and Ilori, E. A. (2014). Foreign Capital Inflows and Growth: An Empirical Analysis of WAMZ Experience. International Journal of Economics and Financial Issues, 4(4):971-983.

Pakenham, T. (1991). The Scramble for Africa. London Abacus.

Palmer, S. and Torgerson, D. J. (1999). Definitions of Efficiency. Bmj, 318(7191):1136.

Pettinger, T. (2017). Technical Efficiency Definition. Retrieved 24th June, 2019, from https://www. economicshelp.org/blog/glossary/technical-efficiency/.

Ramaswamy, K. (1994). Small-Scale Manufacturing Industries: Some Aspects of Size, Growth and Structure. Economic and Political Weekly, pages M13-M23.

Sari, D. W., Khalifah, N. A., and Suyanto, S. (2016). The Spillover Effects of Foreign Direct Investment on the Firms' Productivity Performances. Journal of Productivity Analysis, 46(2-3):199-233. 
Smith, S. C., Cin, B.-C., and Vodopivec, M. (1997). Privatization Incidence, Ownership Forms, and Firm Performance: Evidence from Slovenia. Journal of Comparative Economics, 25(2):158-179.

Sun, P. and Heshmati, A. (2010). International Trade and Its Effects on Economic Growth in China. IZA discussion paper.

Suyanto, M., Bloch, H., and Salim, R. A. (2012). Foreign Direct Investment Spillovers and Productivity Growth in Indonesian Garment and Electronics Manufacturing. The Journal of Development Studies, 48(10):1397-1411.

Suyanto, S. and Salim, R. (2011). Foreign Direct Investment Spillovers and Technical Efficiency in the Indonesian Pharmaceutical Sector: Firm Level Evidence. Applied Economics, 45(3):383-395.

Svedin, D. and Stage, J. (2016). Impacts of Foreign Direct Investment on Efficiency in Swedish Manufacturing. SpringerPlus, 5(1):614.

UNCTAD (2017). World Investment Report 2017: Investment and the Digital Economy. UN, New York, https://doi.org/10.18356/e692e49c-en.

UNCTAD (2018). World Investment Report 2018: Investment and the Digital Economy. UN, New York, https://doi.org/10.18356/ebb78749-en.

UNCTAD (2019). World Investment Report 2019: Investment and the Digital Economy. UN, New York, https://unctad.org/system/files/official-document/wir201 9_en.pdf.

UNCTAD (2020). World Investment Report 2020: Investment and the Digital Economy. UN, New York, https://unctad.org/system/files/official-document/wir202 0_en.pdf.

Vu, H. D. (2016). Technical Efficiency of FDI Firms in the Vietnamese Manufacturing Sector. Review of Economic Perspectives, 16(3):205-230.

Wang, M. and Wong, M. S. (2016). Effects of Foreign Direct Investment on Firm-level Technical Efficiency: Stochastic Frontier Model Evidence from Chinese Manufacturing Firms. Atlantic Economic Journal, 44(3):335-361.

World Bank (2017). Global Investment Competitiveness Report 2017-2018: Foreign Investor Perspectives and Policy Implications. World Bank Group, Washington, D.C., http://documents.worldbank.org/curated/en/169531510741671962/Global-inv estment-competitiveness-report-2017-2018-foreign-investor-perspectives -and-policy-implications. 
Zhou, Y. (2014). FDI and Technical Efficiency in Manufacturing Firms: A Stochastic Frontier Approach. 


\section{A Critical Values for Mixed Chi-Square Distributions}

\begin{tabular}{|c|c|c|c|c|c|c|c|}
\hline df & $\alpha \quad .25$ & .10 & .05 & .025 & .01 & .005 & .001 \\
\hline 1 & 0.455 & 1.642 & 2.706 & 3.841 & 5.412 & 6.635 & 9.500 \\
\hline 2 & 2.090 & 3.808 & 5.138 & 6.483 & 8.273 & 9.634 & 12.810 \\
\hline 3 & 3.475 & 5.528 & 7.045 & 8.542 & 10.501 & 11.971 & 15.357 \\
\hline 4 & 4.776 & 7.094 & 8.761 & 10.384 & 12.483 & 14.045 & 17.612 \\
\hline 5 & 6.031 & 8.574 & 10.371 & 12.103 & 14.325 & 15.968 & 19.696 \\
\hline
\end{tabular}

\section{B Technical Efficiency Prediction}

- predict te, jlms

- sum te

\begin{tabular}{|c|c|c|c|c|c|}
\hline Variable & Obs & Mean & Dev. & Min & $\operatorname{Max}$ \\
\hline te & 1778 & 3040591 & 2241254 & .1361524 & .9919716 \\
\hline
\end{tabular}

